\title{
Why Underachievers Dominate Secret Police Organizations: Evidence from Autocratic Argentina 0
}

\author{
Adam Scharpf GIGA German Institute of Global and Area Studies \\ Christian Gläßel University of Mannheim
}

\begin{abstract}
Autocrats depend on a capable secret police. Anecdotal evidence, however, often characterizes agents as surprisingly mediocre in skill and intellect. To explain this puzzle, this article focuses on the career incentives underachieving individuals face in the regular security apparatus. Low-performing officials in hierarchical organizations have little chance of being promoted or filling lucrative positions. To salvage their careers, these officials are willing to undertake burdensome secret police work. Using data on all 4,287 officers who served in autocratic Argentina (1975-83), we study biographic differences between secret police agents and the entire recruitment pool. We find that low-achieving officers were stuck within the regime hierarchy, threatened with discharge, and thus more likely to join the secret police for future benefits. The study demonstrates how state bureaucracies breed mundane career concerns that produce willing enforcers and cement violent regimes. This has implications for the understanding of autocratic consolidation and democratic breakdown.
\end{abstract}

Replication Materials: The data and materials required to verify the computational reproducibility of the results, procedures and analyses in this article are available on the American Journal of Political Science Dataverse within the Harvard Dataverse Network, at: https://doi.org/10.7910/DVN/PGFOXW.

"We don't want clever people. We want mediocrities."

\section{—Officer, Greek Military Police ${ }^{1}$}

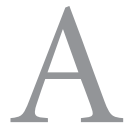
utocracies are notorious for their systematic violation of civil liberties and human rights (e.g., Davenport 2007; Frantz and Kendall-Taylor 2014; Valentino 2004). At the core of autocratic repression stand secret police forces (Arendt 2017; Friedrich and Brzezinski 1965). For centuries, regimes have made extensive use of and largely depended on the loyalty of such organizations (Baldwin 1934; Greitens 2016; Plate and Darvi 1982). Charged with the responsibility to protect the regime from internal and external threats, secret police forces run extensive spying networks to surveil and detect conspiring enemies within the elite, the security apparatus, and society at large. Acting on the suspicion of subversion, units such as Czar Nicholas's Okhrana, Hitler's Gestapo, or Assad's Air Force Intelligence Directorate detained, tortured, and even killed their victims.

The relentless persecution of opponents makes secret police forces indispensable for the survival of autocratic regimes. All the more surprising is that historical studies describe secret police agents as remarkably mediocre in skill and intellect. Many members of Stalin's NKVD, for example, appear to have been poorly educated, lacking the capability of other Soviet bureaucrats (Gregory 2009). This resonates with piecemeal information hinting at the

Adam Scharpf is Postdoctoral Research Fellow, GIGA German Institute of Global and Area Studies, Neuer Jungfernstieg 21, 20354 Hamburg, Germany (adam.scharpf@giga-hamburg.de). Christian Gläßel is PhD Candidate, Department of Political Science, and Researcher, Collaborative Research Center SFB 884: Political Economy of Reforms, University of Mannheim, Parkring 47, 68159 Mannheim, Germany (christian.glaessel@uni-mannheim.de).

We are grateful to Belén González for her continued support in this project. We thank Sabine Carey, Kristine Eck, Alexander De Juan, Felix Haass, Kristen Harkness, Anna-Lena Hönig, Nikolay Marinov, Cosima Meyer, Neil Mitchell, Felix Olsowski, Katrin Paula, Tom Pepinsky, Jan Pierskalla, Constantin Ruhe, Gerald Schneider, Lucia Tiscornia, Christian von Soest, and Claudius Wagemann, as well as the participants of the 2018 PEDD, NEPS, ECPR, and 2019 ISA conferences for helpful feedback. We also thank the three anonymous reviewers and the editors for insightful comments and suggestions. This work was supported by the University of Mannheim's Graduate School of Economic and Social Sciences funded by the German Research Foundation.

${ }^{1}$ The quote refers to the recruitment practice of the Greek secret police (Amnesty International 1977, 31).

American Journal of Political Science, Vol. 00, No. 00, xxxx 2019, Pp. 1-16

(C) 2019, Midwest Political Science Association

DOI: $10.1111 /$ ajps.12475 
poor quality of secret police officers in other countries (Browder 1996; Persak and Kamiński 2005; Plate and Darvi 1982). ${ }^{2}$ However, whether underqualified agents systematically dominated the secret police in any of these cases is still unknown. Notwithstanding this open empirical question, theoretical work rationalizes why dictators might staff key security organizations with incompetent agents (Egorov and Sonin 2011; Zakharov 2016). They suggest that leaders strategically recruit less-skilled officials, whom they deem to be more loyal. We advance these arguments by dissecting the supply side in the recruitment of agents to explain why underachievers want to join the secret police in the first place and why leaders accept them.

We argue that the organizational structure of the regular security apparatus ${ }^{3}$ produces career incentives for less-skilled officials to work in the secret police. In hierarchical organizations, officials with only mediocre achievements in the early stages of their career have little chance of being promoted and gaining lucrative positions either inside or outside the coercive bureaucracy. This generates strong career pressures for underachieving but aspirational officials to demonstrate commitment. The arduous nature of secret police work offers underachievers the opportunity to signal their value to the regime and get ahead of competitors for higher positions. Leaders can exploit these incentives and staff their secret police with zealous officials.

Our theory makes sense of recruitment in regimes with and without salient social cleavages. Studies suggest that in countries with politicized divisions between classes, religions, or ethnicities, autocrats recruit security personnel from favored social groups (Albrecht and Ohl 2016; Greitens 2016; Hassan 2017; Sassoon 2016). Leaders expect these individuals to follow repressive orders out of their shared interest in the regime's survival. Our organizational perspective explains which individuals within these societal segments are most likely to join the secret police. In many other countries, sectarian or social cleavages are too weak or the favored groups too large and heterogeneous to predict individual loyalty. By focusing on the career incentives universal to coercive bureaucracies, our argument also explains which agents are willing to join secret police forces in states without such divisions.

\footnotetext{
${ }^{2}$ Cases include Czechoslovakia, Germany, Greece, Iran, Paraguay, Poland, Romania, South Africa, and Uruguay.

${ }^{3}$ Security apparatus and coercive bureaucracy refer to the state's body of formal security organizations, such as military, police, and intelligence agencies.
}

To test our theory, we draw on Argentina's last dictatorship. The case allows us to study secret police recruitment in a country where sectarian cleavages are absent and respective social classes too large to offer a meaningful rationale for the selection of agents. Our analysis offers systematic evidence on the composition of Intelligence Battalion 601-the most notorious and powerful secret police unit in the history of Argentina. Between 1975 and 1983, Battalion 601 was the operative brain behind the surveillance, detention, and forced disappearance of thousands of Argentine citizens, while assuming a leading role in Operation Condor-a secret rendition network among right-wing dictatorships that targeted individuals across the Western Hemisphere (Dinges 2004; Ministerio de Justicia y Derechos Humanos [Ministry of Justice and Human Rights; MJyDH] 2015).

We collect and analyze original microlevel data on the profiles of officials to find out why individuals want to serve in units designed to oppress societies. To the best of our knowledge, this is the first empirical study on the enrollment of secret police agents. Combining information from various archival sources, we compile a data set of more than 4,000 military officers who constituted the entire recruitment pool for the Argentine secret police. These officers represent all individuals who entered the officer corps between 1947 and 1975. We link this information with recently released data on all agents working in Battalion 601 to study biographic differences between secret police members and their peers in all other parts of the army. The results from our analysis offer strong support for our theoretical expectation and corroborate each part of our theoretical mechanism. Overall, we find that officers who were under severe pressure due to poor performance in their early career stages were more likely to join Battalion 601.

Adopting an organizational perspective, this study offers unique insights into the institutional anatomy of authoritarian regimes. Despite the importance and longlasting consequences of secret police forces for political regimes and domestic societies, the systematic study of such organizations has been hampered by sparse and unreliable information (Barros 2016; Policzer 2009). We expose the clandestine organization at the center of a dictatorship and scrutinize the individual agents who serve in it. Other than psychological predispositions, deep ideological convictions, or strong ethnic identities, we identify mundane but universal career concerns as a prime motivator for officials to engage in arduous secret police work. Leaders exploit these incentives to maximize compliance within organizations that require high levels of operational autonomy to carry out their tasks but that are otherwise difficult to control. Career pressures 
therefore serve regimes as the lubricant of their repressive machines.

\section{Research on Dictators and Coercive Agents}

Studies on coercive institutions usually assume the perspective of governments that are concerned about disobedience within the security apparatus (Bellin 2004; Gregory 2009; Greitens 2016; Hassan 2017; Quinlivan 1999). For autocratic governments, disobedient secret police forces are particularly dangerous, as their refusal to carry out orders commonly marks the end of the leader's rule (Dragu and Przeworski 2019). Secret police agents uncover conspiracies and protect the regime against internal and external enemies, which makes leaders vulnerable to resistance from within those organizations (Greitens 2016; Plate and Darvi 1982). Noncompliance in the core repressive unit reveals the government's weakness and enables opposition groups, rival regime elites, and other security forces to turn against it (Albrecht and Ohl 2016; DeMeritt 2015; Dragu and Lupu 2018).

Leaders seek to prevent these risks with utmost vigor. To deter disobedience and increase the compliance of agents, dictators set up monitoring systems and impose draconian punishments (Gregory 2009; Quinlivan 1999; Sudduth 2017). Yet, control mechanisms are known to be largely ineffective (Brehm and Gates 1999). Monitoring does not alter the preferences of subordinates, and many governments lack the resources to identify and sanction rogue officials (Cole 2015; Conrad and Moore 2010). Such control problems are particularly pronounced with regard to secret police forces (Greitens 2016; Policzer 2009). By design, these units operate in secrecy and with great autonomy to be effective-by necessity, they are experts in espionage and counterespionage (Plate and Darvi 1982, 85-101). As a result, even parallel security forces often struggle to control the secret units ultimately responsible for the regime's protection (Dragu and Przeworski 2019; Gregory 2009). This makes it inherently difficult to keep the secret police in check, and it often allowed these organizations to accumulate tremendous powers-turning them into what some have termed a "state within the state" (Arendt 2017, 556) or a bureaucratic "monster" (Stepan 1988, 16).

Because of these control problems and the devastating consequences from secret police failure, for rulers

\footnotetext{
${ }^{4}$ Training and indoctrination do not guarantee obedience either, as they imperfectly replace personal preferences, which exacerbates control problems if agents enjoy large autonomy (Scharpf 2018).
}

the selection of agents is highly important. Discriminating among security personnel, regimes commonly fill units with officials deemed most suitable (Bellin 2004; Harkness 2016). One might therefore expect that leaders select the brightest and most capable bureaucrats to serve in the secret police (Baldwin 1934; McMahon and Slantchev 2015). Anecdotal evidence, however, suggests otherwise. For example, in communist Poland, members of the Bezpieka secret police have been described as "extremely undereducated," with "no political or social experience" (Dudek and Paczkowski 2005, 242-43). Accounts of the czarist Okhrana, Lenin's Cheka, Hitler's Security Service, the State Security of Czechoslovakia, and other organizations hint at similar patterns (Blažek and Žáček 2005; Browder 1996; Zuckerman 1996). In view of the fact that regimes depend on an effective secret police, these historical descriptions are puzzling.

Two strands of research speak to the recruitment of incompetent officials. The literature on nepotist regimes conceives the selection of low-skilled agents as an unintended side effect of the leader's recruitment decisions. Regarding the assignment of top officials, studies emphasize the centrality of personal connections to the ruler (Slater 2003; Taylor 2011). Sassoon (2016, 124-25), for example, describes how Saddam Hussein appointed his family members to lead the intelligence services irrespective of their expertise. As it is impossible to fill entire organizations with friends and relatives, dictators have been argued to staff important units with members of the social groups deemed most loyal. Both General Qaddafi and President Assad reportedly drew on aligned religious minorities and ethnic tribes to maximize loyalty among their security forces (Quinlivan 1999).

However, ethnicity and socioeconomic class are broad categories that offer only limited information on the personal interests and future behavior of individuals. It is unknown which markers leaders use to select agents from within favored segments of society. According to Sassoon $(2016,124)$, even in countries with highly politicized social cleavages, such as Iraq and Syria, the composition of security organizations is more heterogeneous than is commonly assumed-a fact that current studies do not explain. Furthermore, in many countries, highly salient ethnic cleavages are absent or leaders lack allied socioeconomic strata. In the absence of politically exploitable cleavages, it is unknown how regimes staff their core repressive units.

The second strand of research explicitly discusses potential trade-offs between competence and loyalty to explain why leaders might deliberately employ low-skilled agents. According to Egorov and Sonin (2011), leaders fear that smart officials use their competence to oust them 
in the future. ${ }^{5}$ Zakharov (2016), in turn, expects skilled agents to remain idle once their ruler is in danger, because they consider themselves indispensable under any successor regime. Together, this suggests that leaders have a strategic incentive to select less competent secret police agents for the sake of greater loyalty. Our theory complements and refines these arguments. It dissects the supply side of organizational recruitment to explain why underachieving officials want to join the secret police in the first place. We show that career pressures inherent to regular security organizations drive the very individuals preferred by dictators into the secret police.

\section{A Theory of Careers within Coercive Institutions}

We first examine inherent characteristics of the state's coercive bureaucracy, which typically constitutes the recruitment pool for the secret police, in order to explain how organizational bottlenecks create career pressures for officials with a hitherto weak track record. We then describe why burdensome secret police service offers underachieving officials the opportunity to advance their career and why leaders are likely to accept them into the secret police.

Historically, many secret police forces have recruited personnel from the regime's larger security apparatusincluding the military, gendarmeries, police departments, and conventional intelligence agencies (Browder 1996; Gregory 2009; Greitens 2016; Persak and Kamiński 2005; Sassoon 2016; Zuckerman 1996). These security organizations share three general characteristics that shape the career trajectories and incentives of officials. First, the organizations are hierarchically structured. Members of such institutions generally strive for promotions because rank within the hierarchy determines the amount of personal power, pay, and social prestige (Baker, Jensen, and Murphy 1988, 599; Svolik 2012, 168-69). ${ }^{6}$

\footnotetext{
${ }^{5}$ In contrast to Egorov and Sonin (2011), McMahon and Slantchev (2015) argue that leaders always have an incentive to hire skilled guardians, while limiting their resources. Rulers would hire incompetent agents only if they mistakenly considered them competent. As the authors point out, constituent components of the studies' proposed mechanisms are barely quantifiable and have thus not been systematically tested (Egorov and Sonin 2011, 906; McMahon and Slantchev 2015, 307-11).

${ }^{6}$ Top positions in coercive bureaucracies often entail perks, including priority health care and luxurious housing (Bellin 2004; Brooks 1998), or grant access to exclusive networks of corruption or illegal activities (Droz-Vincent 2007).
}

Second, the organizations are pyramid shaped, with an abundance of positions at the bottom but only few lucrative posts at the top (Blau and Scott 2003, 32). Officials striving for promotion face a declining number of available positions at each career step, and only few individuals can ascend to the highest ranks. These builtin bottlenecks generate competition among junior and midlevel officials for senior billets (Kung and Chen 2011, 29-31). The career pressures are especially pronounced in security organizations with "up-or-out" promotion systems, in which individuals who have been repeatedly passed over for promotion are threatened with forced retirement to make way for the next cohort (Baker, Jensen, and Murphy 1988, 604-5).

Third, in pyramid-shaped organizations, officials climb up the hierarchy until they reach a position where they are no longer competitive against their peers of equal rank (Lazear 2004, 160). Leaders value both competence and loyalty; both traits can be bases for promotion. However, as competence is an observable trait, whereas loyalty is not, the competitiveness of an individual is largely determined by her past performance (Lazear 2004, 159). Officials typically lay the foundation for future advancement at an early stage (Becker and Strauss 1956, 256). The importance of early achievements is particularly well documented for careers within the military. ${ }^{7}$ Cadets who perform well at the academy have better chances of gaining access to higher education facilities, where they acquire management and leadership skills necessary to ascend to the upper echelons. Without such training, officials are likely to be stuck at midlevel ranks and lack the skills for lucrative employment outside the security apparatus (Biderman and Sharp 1968, 388). ${ }^{8}$

Due to these inherent characteristics of security organizations, low-performing officials face grim career prospects. This pressures them into pursuing unorthodox routes by which they can climb up to higher ranks (Kung and Chen 2011,28). One way to improve their own promotion prospects in such circumstances is to apply for unpopular assignments where underachievers can stand out from their peers (Becker and Strauss 1956, 257). We argue that the secret police offers exactly such posts.

\footnotetext{
${ }^{7}$ In prototypical military organizations, "promotions are consistently based on achievement criteria, which include relative standing in one's graduating class from the military academy, [and] attendance at advanced training centers" (Nordlinger 1977, 43). Early performance is even important in nepotist regimes, as personal networks have less impact on promotions at lower ranks (Moore and Trout 1978, 460-61; Sassoon 2016, 106-8).

${ }^{8}$ Civilian employers value managerial and leadership skills rather than purely security-related proficiencies (Janowitz 1988, 64).
} 
In the name of protecting the regime, secret police agents must spy on, intimidate, torture, and even kill people. In contrast to regular police officers or soldiers, agents do not use these measures against ordinary criminals or foreign armies but "more or less arbitrarily selected classes of the population" (Friedrich and Brzezinski 1965, 22). This requires agents to regularly perpetrate repression that defies moral norms, incurs social stigma, and entails high psychological burdens even for trained specialists (Grossman 1996, 222-26; Huggins, Haritos-Fatouros, and Zimbardo 2002, 214-31). ${ }^{9}$ Brazilian secret police officers, for example, "manifested such stress-related symptoms as insomnia, hypertension, fear, and depression [...] exacerbated by an inability to talk about their work" (Huggins, Haritos-Fatouros, and Zimbardo 2002, 15). Compared to service in the regular security apparatus, secret police work is emotionally much more "difficult, arduous, and exhausting" (Plate and Darvi 1982, 128). High-performing officials, who do not face career pressure, therefore have little incentive to engage in burdensome secret police tasks (Browning 1998, 169). For underachievers, this reduces the competition from peers with hitherto superior achievements and improves their prospects for promotion within the secret police.

Furthermore, pressured officials with poor past performance have an incentive to join the secret police because they can expect that those who carry out undesirable secret police tasks send a signal of commitment to the regime. As secret police agents, they have the opportunity to build a reputation of being loyal and zealouscharacteristics that are highly valued by both superiors and leaders. In the words of a Uruguayan officer, repressive zeal was "rewarded by the authorities either in promotion or in assignment" (Plate and Darvi 1982, 141). While officials have difficulties proving such reliability in the regular security apparatus (Moore and Trout 1978, 455-56), secret police service allows agents to manifest their loyalty. Underachievers may therefore hope that their service in the secret police will not only improve their prospects for promotion within the secret police itself but also open doors to higher ranks back in the regular security apparatus. Anecdotal evidence suggests that underachieving agents do indeed see their secret police service as an opportunity to salvage their faltering careers. In Nazi Germany, for example, police officers "blocked by the 'bottleneck' of seniors ahead of them" sought to join the Gestapo-anticipating that they "lacked any hope of

\footnotetext{
${ }^{9}$ Agents may also worry about future repercussions, as dictators' henchmen are often the first to be held accountable (DeMeritt 2015).
}

status" otherwise (Browder 1996, 22, 83). ${ }^{10}$ Driven by the hope of future reward and promotion, underachieving officials are therefore likely to put themselves forward for the secret police.

Regimes, on the other hand, have good reasons to admit underperformers to their key coercive unit and to not counteract the self-selection of such officials. From the perspective of leaders, underachievers are beneficial because they must diligently work toward the autocrat's interests to retain their career chances. For example, Alexandru Drăghici, the former interior minister of Romania, was well aware that his secret police agents "had a fairly low level of training and general knowledge, but that these shortcomings were compensated for by their powerful revolutionary enthusiasm" (Deletant 2005, 304). By contrast, leaders who assign high-performing officials to serve in the secret police must fear that their subordinates will not execute unpleasant orders. Having lucrative career options, competent officials make unreliable secret police agents, as they are likely to stay passive when the regime is under attack (Zakharov 2016).

In the extreme case, leaders have to worry that capable agents even use their competence to actively work against the government or seize an all-dominant position in the regime (Egorov and Sonin 2011; Geddes, Wright, and Frantz 2018). Such risks are lower when it is not the most capable officials but rather loyal mediocrities who are entrusted with the leaders' protection. In this way, the regime can fully benefit from top performers working within the regular security apparatus or the larger regime bureaucracy while exploiting the career pressures of underachievers to forge a loyal secret police. Finally, direct superiors within the secret police, who joined the force because of their own weak performances, should also favor less-skilled subordinates. Acting upon their own career concerns, superiors hope that underachieving subordinates will not compete with or supersede them. This strengthens the career prospects for agents with weak performances. Given the overlapping incentives of the regime and its agents, we expect that officials with inferior past achievements are more likely to serve in the secret police.

\section{Empirical Case}

We focus on Argentina's last dictatorship to unearth, triangulate, and analyze data on officials in the secret police

\footnotetext{
${ }^{10}$ Similarly, Polish functionaries saw the secret police as a vehicle for social advancement (Dudek and Paczkowski 2005, 243). Paraguayan officials who "could not make it up the ranks" (Plate and Darvi 1982, 134) took over the unpopular task of torture.
} 
and the surrounding security apparatus. Sparse information has constrained research on authoritarian institutions (Barros 2016; Geddes, Wright, and Frantz 2018; Policzer 2009). Past regimes thus offer the best opportunity to study secret police forces and their internal composition (Balcells and Sullivan 2018). To the best of our knowledge, the case of Argentina is unique in that it permits us to systematically test whether and why underperformers are more likely to serve in the secret police.

\section{Argentina's Coercive System}

The coercive system of 1970s Argentina comprised regular law enforcement agencies and the military, as well as a number of civil and military intelligence services. The latter included the state intelligence secretariat, the superintendence of the federal police, and the regular intelligence agencies of the army, navy, and air force (MJyDH 2015). Throughout Argentina's modern history, the army held a key position inside this system, repeatedly intervened in politics, and ousted several democratically elected governments (Potash 1996). Despite these interventions, the army's recruitment, training, and promotion system resembled a prototypical security organization with a hierarchical and meritocratic structure (Atkins and Thompson 1972). ${ }^{11}$ With an up-or-out system in place, military officers faced considerable career pressures from the outset. Figure 1 depicts the strong relationship between early performance at the military academy and subsequent advancement to the highest positions. Cadets who graduated at the top of their class were much more likely to rise to the general ranks, whereas most graduates at the bottom of their class had to leave the organization as midlevel officers.

\section{Intelligence Battalion 601}

Between 1975 and 1983, Argentina's security forces faced violent uprisings by two insurgent groups: the People's Revolutionary Army and the left-wing Peronist Montoneros. In response, the military pressured the democratic government of Isabel Perón for far-reaching powers; by 1975, the army was in charge of all matters of internal security (Heinz 1999, 621-33, 680-85). Despite their authority, generals led by Jorge Videla ousted Perón

\footnotetext{
${ }^{11}$ Successful military careers typically featured good academy performances, first assignments as junior officers, and advanced training at the Higher War School. High-performing midlevel officers later managed larger units or acquired staff positions before becoming generals.
}

\section{FIGURE 1 Graduate Performance and Career Achievement}

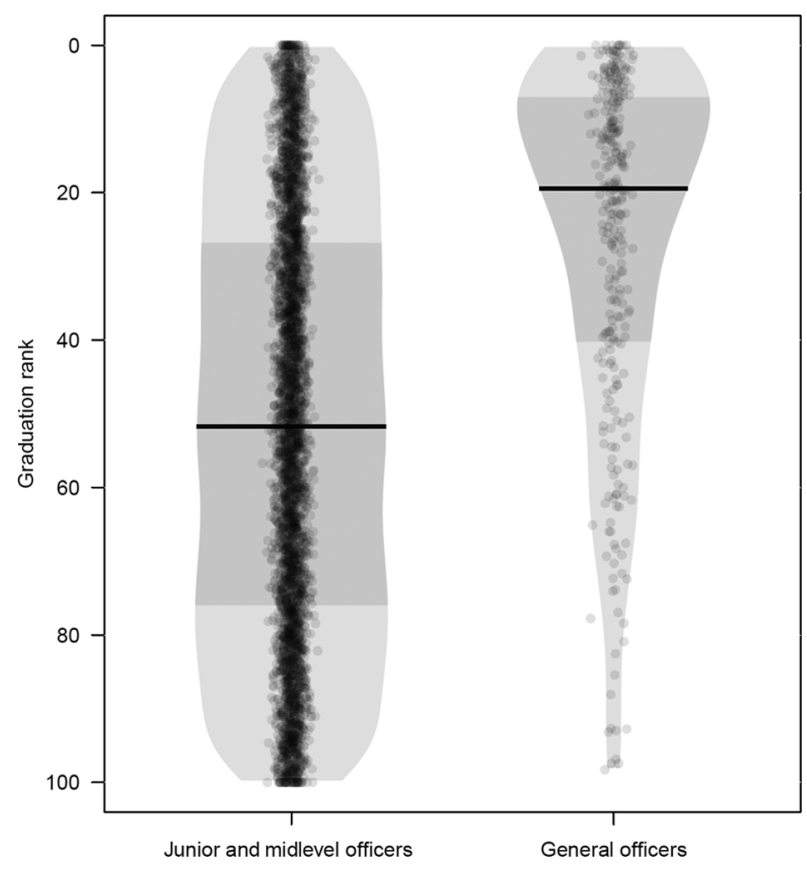

Note: The plot shows the relationship between officers' performances at the military academy and subsequent career achievements. Graduation rank gives each officer's placement relative to her respective cohort at the academy. The rank of zero identifies the best-performing officers. Junior and midlevel officers and general officers denote ranks at retirement. Gray areas denote probability densities, dark areas indicate interquartile ranges, and black lines give medians.

in March 1976. Political power now was in the hands of a junta called the "National Process of Reorganization" (Lewis 2002, 131-32). ${ }^{12}$

For the military, the insurgent uprisings constituted clear signs of a Soviet-supported attempt to take over Argentina and indeed the Western Hemisphere. The junta was convinced that the insurgent groups were only the visible manifestations of a clandestine enemy that operated from within the Argentine society (Lewis 2002, 13743). Intelligence therefore turned into the key resource in uncovering and destroying subversive networks. In this context, Intelligence Battalion 601 became the secret police unit centrally responsible for the nationwide targeting of thousands of alleged subversives (MJyDH 2015).

To streamline the state's repressive capacities, the military leadership established Battalion 601 as the single

\footnotetext{
${ }^{12}$ Our results are not affected by changes in junta personnel or rebel capacity (see supporting information [SI], Section SI.4, 21-22).
} 
most powerful organization "to which all other security units were subordinate" (Dinges 2004, 112). Directly reporting to the junta and the General Army Command, the battalion possessed what Greitens calls "coordinating authority" $(2016,25) \cdot{ }^{13}$ All conventional intelligence agencies and regular army units had to pass their intelligence on to 601 (MJyDH 2015, 11-29). Battalion agents processed all incoming information before feeding it back into the coercive system, as well as up or down the chain of command. At the same time, 601 collected its own intelligence and conducted a huge number of repressive operations. In short, "disappearance [was] 601 work" (National Security Archive [NSA] 2002a, 1).

Internally, Battalion 601 consisted of three departments. ${ }^{14}$ Central de Contrainteligencia, in charge of counterespionage, and Central de Apoyo, responsible for logistics, were overseen by the battalion's vice chief. The third department, called Central Reunión, constituted the operational heart of Battalion 601 and was in charge of ground-level policing and capture-or-kill missions (MJyDH 2015, 24-29). It enjoyed great autonomy and reported to the chief of 601 only. To repress coarsely defined target groups, Central Reunión harbored seven task forces. ${ }^{15}$ The agents infiltrated organizations, spied on citizens, and disappeared alleged subversives. Victims were typically kidnapped and deported to one of the secret detention and interrogation centers, where most of them were tortured and eventually killed (Lewis 2002, $147-59) .{ }^{16}$

\section{Transitioning to the Battalion}

As Battalion 601 originated from the army, military officers could join the battalion and return to the regular security apparatus with relative ease. Before entering 601, officers had worked in conventional army units, on military bases, or at army headquarters. In these positions, most officers trained enlisted ranks and assisted superiors with the administration of the army. Some of them also commanded units in regular military operations against insurgents (MJyDH 2015, 131-62). According to a former 601 agent, there were no specific entry requirements or special processes governing the transition to the battal-

\footnotetext{
${ }^{13}$ See SI.2 (4) for visualizations of Argentina's coercive system and 601 's central position.

${ }^{14}$ SI.2 (5) provides an organizational chart.

${ }^{15}$ SI.2 (5) offers information on the task forces.

${ }^{16} \mathrm{SI} .2$ (6) provides a mission report on a capture-or-kill operation by 601 task force officers.
}

\section{FIGURE 2 Rank Distribution within Battalion} 601

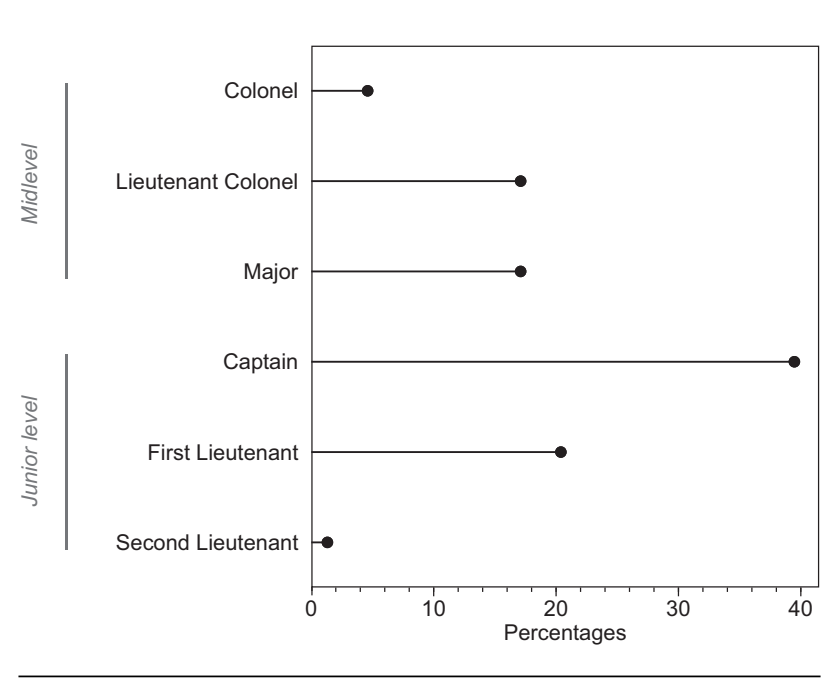

ion. ${ }^{17}$ In general, every year soldiers could formally state their preferences for serving at specific locations or joining particular army units. Prospective secret police members could voice their desire to serve in 601 , which was then decided on by the general staff. Figure 2 shows that, in particular, junior officers switched over to the secret police unit. ${ }^{18}$ Upon admission, 601 commanders unilaterally assigned agents to one of the departments within the battalion. On average, agents served in the unit for almost 3 years. Many of them reentered the regular security apparatus after their secret police service.

\section{Internal Validity}

The case of Argentina's last dictatorship and its coercive system allows us to test crucial components of our argument and to rule out alternative explanations. Argentina is an ethnically and religiously homogeneous society. From 1890 to 1940, Prussian military advisors professionalized the Argentine army, turning it into a merit-based organization (Atkins and Thompson 1972). Explanations based on favoritism are therefore unlikely to confound our analysis.

Furthermore, 601 exclusively recruited members of the Argentine officer corps, which enables us to compare early career performances and isolate their effects. As part of the regular armed forces, the battalion employed the

\footnotetext{
${ }^{17}$ Information is based on the authors' interview with a former Battalion 601 agent (August 2018).

${ }^{18}$ Colonels served as Battalion chiefs, and lieutenant colonels headed individual departments. Regression results do not change when we exclude midlevel officers (SI.4, 20).
} 
same military rank structure and promotion schemeswhich facilitated transitions to 601 and a smooth reintegration into regular units afterward. Finally, formal entry requirements and selection procedures did not change during the junta's rule. The case is therefore well suited to empirically test our theory.

\section{Data and Method}

We compile an original data set to assess whether underachieving officers were more likely to serve in Argentina's secret police. Using recently published information by the Argentine Ministry of Justice and Human Rights, we identify all officers who served in Battalion 601 (MJyDH 2015). We link this list to data on each officer's professional career record (Figueroa 2008). These data stem from more than 20 army and government archives, offering unique information on all 4,287 army officersincluding all 152 Battalion 601 members who graduated from the Colegio Militar de la Nación, the army's officer academy. Our final data set comprises all 30 officer cohorts who graduated between 1947 and 1975. In each cohort, at least one officer served in 601. Officers who did not serve in the battalion but worked in any other army unit function as counterfactuals in the empirical analysis.

The unit of observation in our data set is the individual officer. Our dependent variable is binary, identifying each officer who served in Battalion 601 at any point between 1975 and $1983 .{ }^{19}$ Officers who never joined the battalion are coded as 0 . Given the type of our dependent variable, we employ logistic regressions with standard errors clustered on officer cohorts in the main analysis. ${ }^{20}$

Our key independent variable is Graduation rank, which measures each officer's performance at the officer academy relative to her cohort (Figueroa 2008). ${ }^{21}$ The variable captures the relative educational performance at the beginning of the officer's career with

$$
\text { Graduation } \operatorname{rank}_{i, j}=\left(\frac{\operatorname{Rank}_{i}-1}{\text { Cohort size }_{j}-1}\right) * 100,
$$

where Rank is the absolute position of an officer $i$ among her peers and Cohort size is the total number of cadets

\footnotetext{
${ }^{19}$ SI.1 (3) shows summary statistics.

${ }^{20}$ We replicate all results using matched samples and ordinary least squares with birth province and cohort fixed effects (SI.4, 19, 2324).

${ }^{21}$ As in other officer academies, such as West Point, academic achievements and military leadership performance accounted for roughly $80 \%$ of the final grade, and the rest was a combination of athletic performance and disciplinary record.
}

who graduated with officer $i$ in cohort $j$. Graduation rank ranges from 0 to 100, with larger values indicating worse relative performances. Officers with excellent grades who graduated at the top of their class receive a value of 0 , whereas underachieving officers who graduated at the bottom of their class receive a value of 100 . Higher values of Graduation rank should therefore predict greater probabilities of serving in Battalion 601.

We include several pretreatment variables in the statistical analysis to account for potential confounders. Officers may have held strong ideological convictions or come from influential social classes, which could have affected their graduation performance and motivated them to serve in the secret police. In Argentina, social class and ideological convictions clustered in army branches (Scharpf 2018). Nationalist officers of low socioeconomic status mostly served in the infantry branch, whereas cavalry officers usually came from influential military families of the comparatively liberal upper class. The binary variables Cavalry officer and Infantry officer indicate whether an individual joined the respective branch.

Performances at the academy may have also been affected by the quality of primary education. Educational quality is likely to influence professional achievements, shape upward mobility, and correlate with willingness to serve in 601. Since fine-grained socioeconomic data are unavailable before 1975, we calculate the variable Home literacy rate, measuring the literacy rate in each officer's home province (Lupu and Stokes 2009). ${ }^{22}$ The variable Cadet age controls for an officer's age upon entering the academy. Young, ambitious cadets may have shown little hesitation about serving in 601 to boost their careers, while lacking the experience or skills needed to do well at the academy.

We further account for the content of military training, as it may affect both performance and willingness to join the secret police. Training under military government is a proxy for exposure to repressive counterrevolutionary training. It measures the share of training (percentage) that cadets completed under former military rule (Geddes, Wright, and Frantz 2014). Finally, graduation results may hinge on the amount of time officers spent at the academy. Officers may have taken more time because they had problems completing the coursework, or as a way to strategically reduce course load and improve their grades. We therefore control for Training length, measuring the number of months an officer spent at the academy.

\footnotetext{
${ }^{22}$ Data are available only for election years. We code the literacy rate of the first election year after the officer's birth year.
} 


\section{Figure 3 Battalion 601 Members vs. Other Army Members by Academy Performance}

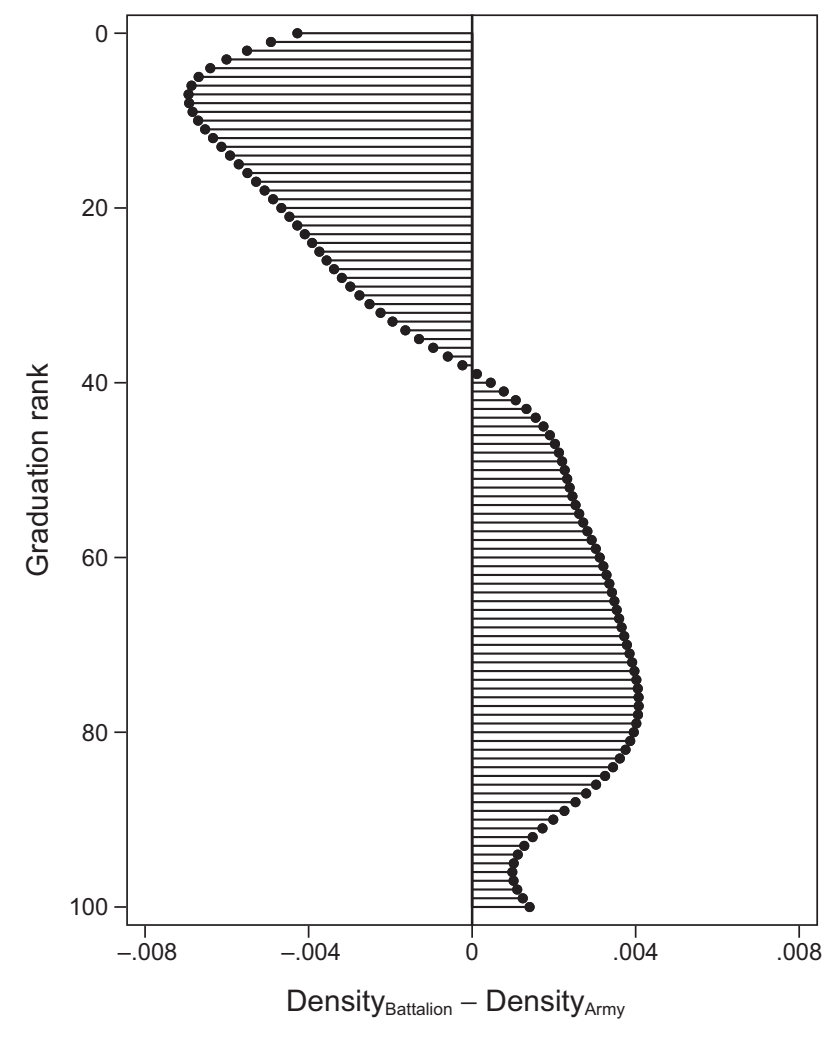

Note: For each graduation rank, a black dot shows the difference in densities between Battalion 601 members and officers in any other unit. Positive $\mathrm{x}$-values indicate that a given graduation rank was overrepresented among 601 members. Negative $\mathrm{x}$-values indicate that a given graduation rank was underrepresented among 601 members.

\section{Empirical Results}

Were underachieving officers more likely to serve in Battalion 601? Anecdotal evidence suggests that members did indeed lack ability. In 1979, a 601 member who served as an informant to the U.S. embassy acknowledged that the unit did not consist of the "best men" (NSA 2002b, 7). Descriptive evidence corroborates this statement. Figure 3 shows that, relative to other army units, in Battalion 601 low performers were overrepresented. This lends initial support to our argument that underachieving officers were more likely to serve in the secret police.

Turning to the results of the statistical analysis, Table 1 shows that Graduation rank is statistically significant and positively correlated with membership in Battalion 601. Officers who underperformed at the mil- itary academy were more likely to serve in the regime's secret police unit. The finding is stable across different model specifications. Results for the control variables show that the officers' backgrounds also mattered. The statistically significant, positive estimate for Infantry officer and the nonsignificant coefficient for Cavalry officer show that infantry officers were more likely to serve in 601. This indicates that officers from lower classes without extensive personal connections were more willing to join the battalion. The positive, statistically significant estimate for the variable Training under military government indicates that officers who underwent training during previous military dictatorships were more likely to serve in the battalion. Cadets' age, quality of primary education, and training length at the military academy are not significantly correlated with battalion membership.

To gauge the effect size of our key finding, we calculate predicted probabilities for an average infantry officer across all values of Graduation rank, holding other control variables at their means (King, Tomz, and Wittenberg 2000). Figure 4 shows that an infantry officer who graduated at the top of her class had an average probability of $0.025(0.02-0.04)$ of serving in the battalion. For the same officer graduating at the bottom of her class, the probability of joining Battalion 601 was 0.09 (0.05-0.14) —a 360\% increase. This result shows that officers with weak performance at an early career stage were more likely to serve in the secret police. Next, we substantiate the core aspects of our theoretical mechanism with empirical evidence.

\section{Probing the Mechanism}

Our argument consists of several steps. In security organizations with an up-or-out system, underperforming officials face early retirement. Such officials have difficulties in reaching higher ranks, as poor past performances impair access to advanced training. In view of these grim career prospects, officials are eager to join the secret police, as it offers a promising alternative way to stay in the security apparatus and reach higher ranks. Regimes can exploit the incentives of underachievers by accepting them into the secret police. We offer evidence for each step.

\section{Early Performance and the Risk of Retirement}

The first component of our mechanism postulates that up-or-out promotion systems produce great career 
TABLE 1 Logistic Regressions for Battalion 601 Membership, 1975-83

\begin{tabular}{lcccc}
\hline & $(1)$ & $(2)$ & $(3)$ & $(4)$ \\
\hline Graduation rank & $0.014^{* * *}$ & $0.014^{* * *}$ & $0.014^{* * *}$ & $0.013^{* *}$ \\
& $(0.004)$ & $(0.004)$ & $(0.004)$ & $(0.004)$ \\
Cavalry officer & & $-0.780^{* *}$ & -0.551 & -0.563 \\
& & $(0.298)$ & $(0.308)$ & $(0.310)$ \\
Infantry officer & & $0.517^{* *}$ & $0.507^{* *}$ \\
& & & $(0.171)$ & $(0.173)$ \\
Home literacy rate & & 1.291 & 0.992 \\
& & & $(0.694)$ & $(0.777)$ \\
Cadet age & & 0.001 & 0.006 \\
& & & $(0.006)$ & $(0.005)$ \\
Training under military gov. & & & $0.007^{*}$ \\
& & & & $(0.004)$ \\
Training length & & & 0.008 \\
& & & & $(0.010)$ \\
Constant & $-4.058^{* * *}$ & $-3.968^{* * *}$ & $-5.513^{* * *}$ & $-7.176^{* * *}$ \\
& $(0.189)$ & $(0.190)$ & $(1.535)$ & $(1.469)$ \\
AIC & $1,295.09$ & $1,289.00$ & $1,272.73$ & $1,263.34$ \\
Wald $\chi^{2}$ & $14.18^{* * *}$ & $20.86^{* * *}$ & $28.86^{* * *}$ & $44.34^{* * *}$ \\
Pseudo R & 0.02 & 0.02 & 0.03 & 0.04 \\
Observations & 4,287 & 4,287 & 4,216 & 4,216 \\
\hline
\end{tabular}

Note: Coefficients with robust standard errors are clustered on cohorts.

${ }^{*} \mathrm{p}<.05,{ }^{* *} \mathrm{p}<.01,{ }^{* * *} \mathrm{p}<.001$.

pressures for underperforming officials. If correct, weak achievements at the academy should increase both the officers' risk of (early) retirement and likelihood of serving in 601 . We test this implication with a refined coding of our dependent variable and assess how graduation rank influences the probability of serving in any unit other than Battalion 601, retiring from the army, or working in the battalion. ${ }^{23}$ Results support our expectation. Predicted probabilities, shown in Figure 5, indicate that strong academy performance is positively correlated with longer service in the army (a). In contrast, weak achievements increase the likelihood of both retirement (b) and service in 601 (c). Officers threatened by early retirement turned to the battalion in the hope of salvaging their careers.

\section{Limited Access to Advanced Training}

We have argued that officials with weak graduation results are stuck in the security apparatus because they are less likely to receive advanced training - a prerequisite for future promotions and a successful career. If correct,

${ }^{23}$ The coding for each officer is mutually exclusive due to the crosssectional data structure. See SI.3 $(7,9)$ for coding description of the dependent variable and multinomial regression results. graduation rank should be negatively correlated with the likelihood of such training. To test this, we code a binary variable indicating whether officers attended advanced training centers. ${ }^{24}$ Results offer strong support for this part of our mechanism. Predicted probabilities in Figure 6 show that officers with low early-career performance were unlikely to undergo advanced training, and therefore they were disadvantaged in the competition for lucrative positions within and outside the coercive bureaucracy.

\section{Rewards for Secret Police Service}

Our mechanism also suggests that underachieving officials join the secret police in the hope of improving their bleak career prospects. Qualitative evidence indicates that many 601 agents gained access to advanced training at the Higher War School over the course of their secret police service. Upon completion, officers returned to regular army units or the general staff. Some later transitioned to Argentina's federal and provincial police, or they pursued careers in civil intelligence agencies. Few officers even left

\footnotetext{
${ }^{24}$ We code graduations at the Higher War School, Higher Technical School, or Army Information School.
} 


\section{FIGURE 4 Graduation Rank and Likelihood of Serving in Battalion 601}

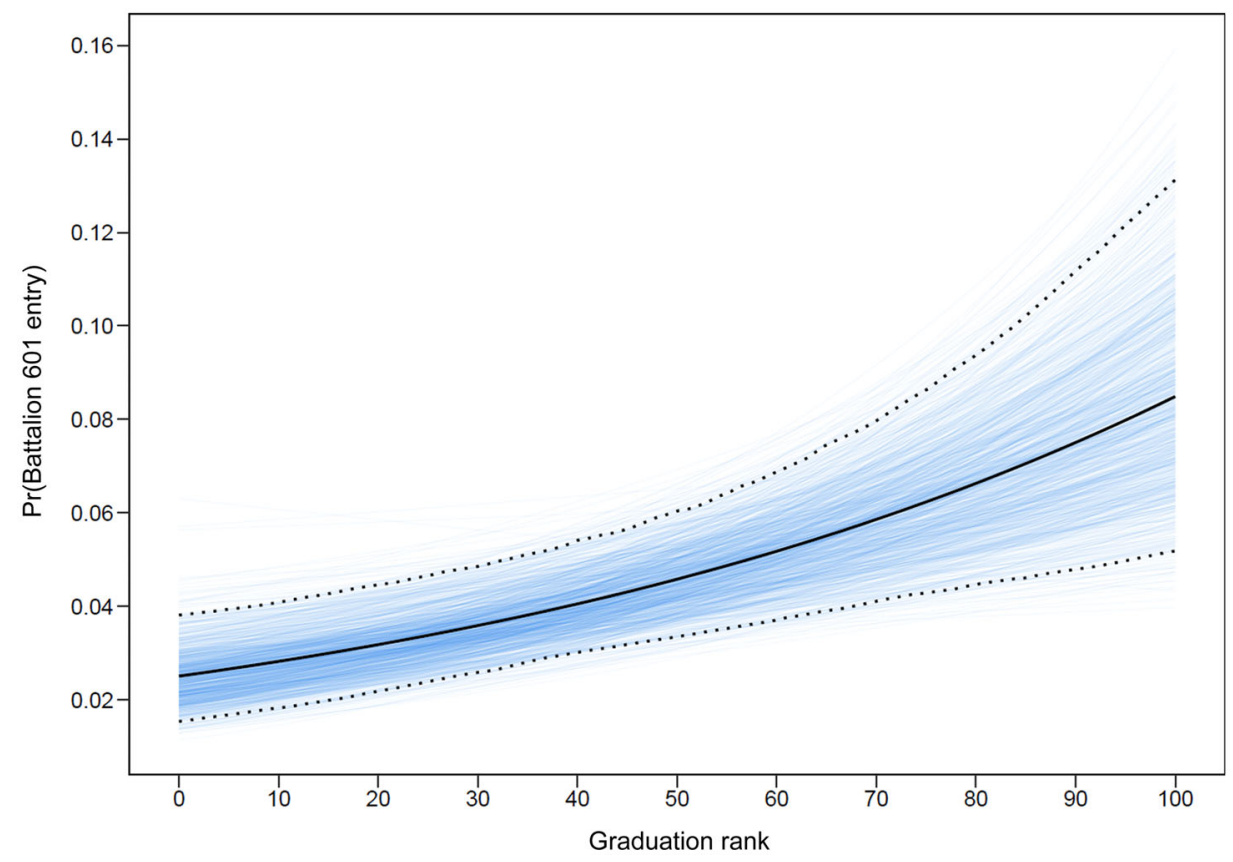

Note: The plot shows predicted probabilities for 601 membership with $95 \%$ confidence intervals for an average infantry officer, who was 18 years old when entering the academy, grew up in a province with an $83 \%$ literacy rate, and underwent about 4 years of training, half of it under military governments (based on Model 4 in Table 1).

\section{FIGURE 5 Early Achievements and Career Outcomes}

(a) Stay

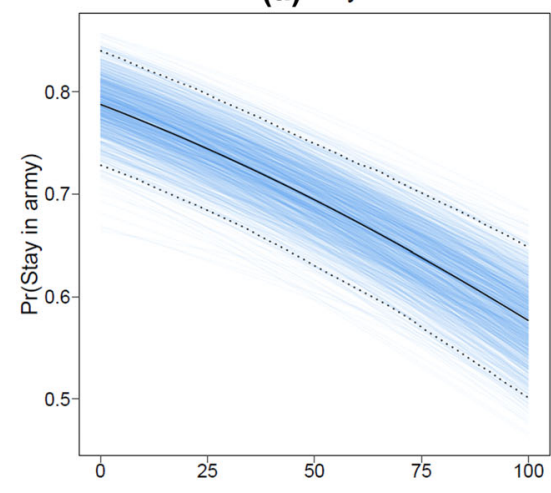

(b) Leave

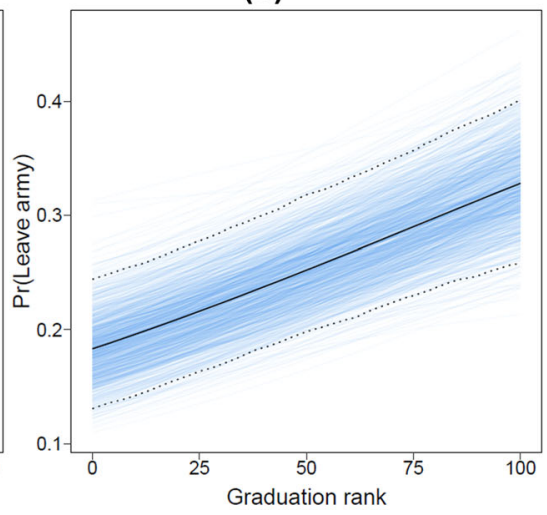

(c) Bn 601

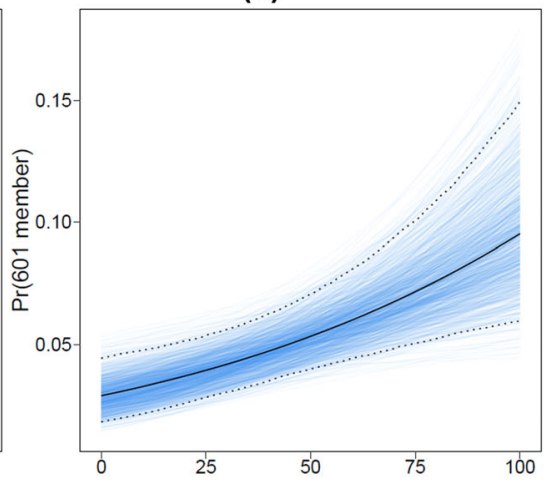

Note: The plots show predicted probabilities for career outcomes (a: continued service in army; b: retirement from army; c: service in 601) at different graduation ranks with 95\% confidence intervals (based on Model 2 in Table SI.3.1, 9).

the security apparatus for positions in the state administration (MJyDH 2015, 131-62).

Quantitatively, we analyze two reward types: service time and rank at retirement. If secret police agents are rewarded for their service, they should remain longer in the security apparatus and ascend to higher ranks than their peers. Using coarsened exact matching, we test whether 601 membership increased service time and rank at retirement. ${ }^{25}$ Figure 7 shows that officers of Battalion

${ }^{25}$ Officers are matched on graduation rank and cohorts to compare individuals with similar track records. SI.3 (10-11) provides imbalance statistics and regression results for both outcome variables. 
Figure 6 Early Career Performance and Access to Advanced Training

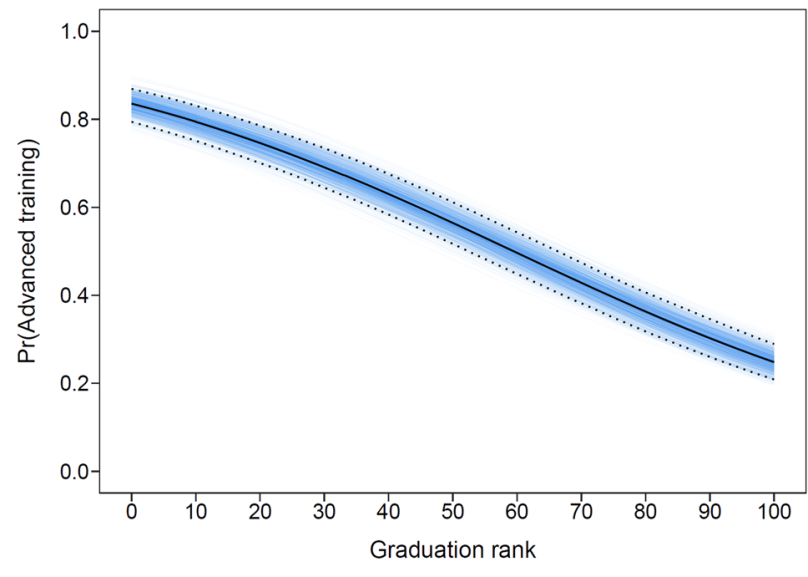

Note: The plot shows predicted probabilities for advanced military training, with $95 \%$ confidence intervals (based on Model 2 in Table SI.3.2, 9).

\section{FigURE 7 Battalion 601 Membership and Service Time in Army}

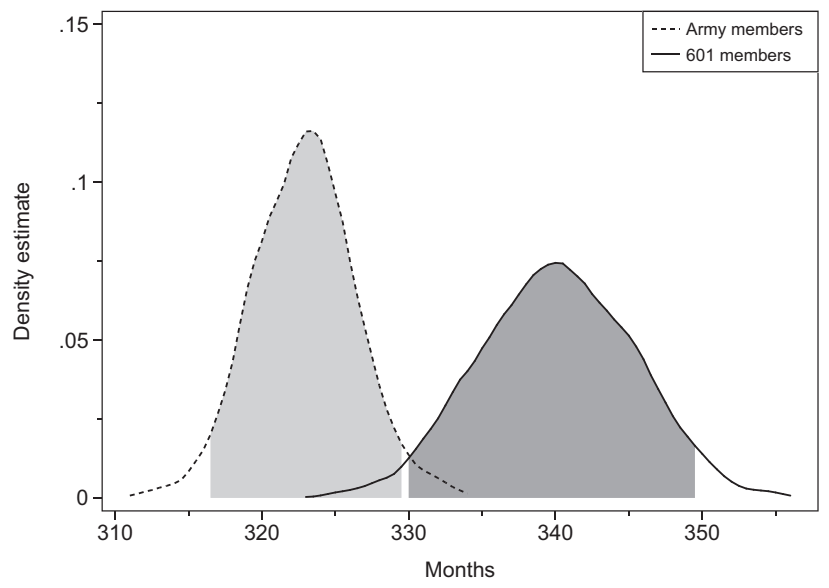

Note: Plot shows density estimates for the total service time in the army comparing matched officers with and without service in 601 ; gray areas denote $95 \%$ confidence intervals (based on Model 4 in Table SI.3.4, 10).

601 indeed served longer in the army than officers who never joined the unit. On average, 601 membership granted agents 16 additional months in the military. This is a substantive but conservative effect estimate, since several officers implicated in repression faced discharge after the junta's demise in 1983. The additional service time came with higher military ranks at retirement as well as gains in income and pension rights. ${ }^{26}$ The Argentine regime rewarded agents for secret police service.

\section{Internal Placement of Secret Police Agents}

Drawing on theoretical literature (Egorov and Sonin 2011; McMahon and Slantchev 2015; Zakharov 2016), our argument suggests that leaders can exploit the career pressures of underachieving officials. This part of our mechanism is most difficult to test. We therefore rely on an observable implication inspired by anecdotal evidence from Nazi Germany: The leadership was careful to assign well-educated members of the secret police to administrative positions, whereas agents with poor track records were tasked with hands-on repression (Browder 1996, 187-88). For Argentina, this suggests that the junta should have placed low-performing members in Central Reunión of Battalion 601, which required the highest loyalty and was most directly involved in ground-level policing. The implication rests on the assumption that incoming officers hoped for a positive impact from secret police service on their career, but had little knowledge regarding which department within Battalion 601 would be best suited to help them achieve this goal. We believe that this is a plausible assumption given the secrecy surrounding the battalion's internal structure and the information by a former 601 member that leaders alone decided over placements within the unit. To further rule out the possibility that agents knew about the respective purposes of the different departments, the test exclusively focuses on the initial positions of incoming members right after the creation of Battalion 601 as the secret police. ${ }^{27}$

The refined dependent variable identifies the first position that officers held within Battalion 601. It distinguishes between officers who served in Central Reunión and officers who worked in another 601 unit. Graduation rank should be positively correlated with the probability of serving in Central Reunión. Results from logistic regressions and Heckman selection models show that low-performing officers were indeed more likely to serve in Central Reunión when entering Battalion 601. ${ }^{28}$ The regime seems to have strategically exploited the career pressures of underachieving individuals by assigning them to specific branches of the secret police.

${ }^{26}$ SI.3 $(11,15-16)$ offers additional tests and visualizations, showing that service in Battalion 601 increased the chances of reaching higher ranks, particularly for officers with weak graduation results.

${ }^{27}$ We analyze internal placements in the first 5 years of the battalion's existence.

${ }^{28}$ See SI.3 (12-13). 


\section{Internal Promotions}

Finally, we have argued that career concerns of direct superiors might reinforce the dominance of underachievers in the secret police. Superiors who have joined the secret police due to their own career pressure should favor underachieving subordinates, as these pose less competition and are unlikely to supersede them. Since direct superiors have little say in recruitment questions, but can influence internal promotion decisions, we scrutinize promotion patterns within Battalion 601. If superiors valued underachievers, graduation rank should have had less effect on internal promotions than in the rest of the army. We code a binary variable indicating whether agents advanced in rank during their service in 601. The results from our statistical analysis suggest that performance at the military academy is indeed an insignificant predictor of promotions within the battalion (SI.3, 13, 16-17). The incentives of direct superiors in the secret police seem to have mitigated the otherwise strong relationship between early career performance and promotion prospects. This underscores that secret police service provides underachieving officials with an exceptional opportunity to salvage their career.

\section{External Validity}

Our findings can offer insights into numerous cases. The organization of Argentina's security apparatus and the close association between the army and the secret police are most representative of military regimes (Geddes, Wright, and Frantz 2014). Similar historical cases include the dictatorships of Brazil and Chile, whose secret police forces also originated from the military (Greitens 2016; Policzer 2009; Stepan 1988). The logic of our theoretical argument should, however, also travel to autocracies that have a strategic incentive to limit institutional and personnel overlaps between the secret police and the military. Hybrid and personalist regimes often rely on security organizations like the regular police or paramilitary forces (Geddes, Wright, and Frantz 2018; Hassan 2017). Although these organizations may not employ strict up-or-out systems, their hierarchical structure with a limited number of top posts generates competition among junior officials. Resulting career pressures are likely to produce similar incentives for underachievers to join the secret police.

Our theoretical argument may also inform the composition of secret police forces in party-based regimes where security and party apparatuses form "interlocking pyramids" (Sassoon 2016, 38). Young party members often have to zealously carry out dirty work like surveillance and intimidation to make it to the top (Svolik 2012, 16869), again closely resembling the career pressures of junior Argentine army officers (Kung and Chen 2011, 28). Our theory predicts that ambitious cadres with weak prospects for advancement in the party hierarchy are likely to provide the human resources for secret police units within such regimes.

This study might also speak to intelligence services in democracies. Contrasting with autocratic secret police forces that uphold the iron rule of despots, democratic intelligence agencies are supposed to protect the general public. Even though such service is surely less arduous, threats to national security sometimes also require agents in democracies to intervene in citizens' rights through nationwide spying or enhanced interrogation programs. Such contingencies might deter high performers, whereas officials under strong career pressure are not in the position to decline assignments. Career concerns could therefore also shape the composition of democratic intelligence units facing trade-offs between national security and civil liberties.

Apart from that, several factors might moderate the general applicability of our mechanism. First, senior officials of competing intelligence organizations might put more emphasis on competence to outdo rival apparatuses. Such competition is common in coup-proofed personalist dictatorships. Second, over time, exceptionally durable dictatorships might be better able to nurture both competent and loyal secret police forces through lifelong indoctrination efforts. ${ }^{29}$ Third, in stable and less violent regimes, secret police work may be less arduous and thus less well suited to demonstrate individual loyalty. This may increase the willingness of high performers and reduce the incentives for underachievers to join the secret police. Fourth, in societies with deep ethnic or social cleavages, some leaders may hope to ensure the loyalty of secret police agents solely by recruiting from favored groups. By contrast, even in highly polarized societies, leaders who fear coups by competent individuals should have an incentive to employ underachievers from within favored groups and exploit their career pressures to maximize loyalty.

${ }^{29}$ The Argentine regime lasted for 8 years, which is marginally longer than the most common regime spell and slightly shorter than the median duration of all autocracies since World War I $(\mathrm{SI} .2,6)$. 


\section{Conclusion}

Why do underqualified agents dominate the secret police? We highlight officials' motivation for serving in secret police organizations to explain this puzzle. In bureaucracies, officials with limited past achievements are forced to demonstrate their commitment in order to improve their chances of gaining future promotions and lucrative positions. Under pressure to outperform their better-qualified peers, such underachievers have large incentives to diligently work in the key coercive unit and show their loyalty to the regime. Underachieving but ambitious officials therefore fulfill the single most important requirement of secret police agents-a strong personal interest in compliance. Leaders who depend on a loyal secret police force can expect individuals motivated by self-preservation to loyally execute violence.

The quantitative analysis of Battalion 601, one of the most notorious intelligence units in the Western Hemisphere, provides empirical evidence for our argument. Drawing on original individual-level data on more than 4,000 officers, we show that those who underperformed early on in their careers were indeed more likely to serve in the battalion. Our results also demonstrate why this was the case. Top performers at the academy were more likely to attain advanced training and high-ranking regime positions, whereas most low performers were stuck at middling ranks or even had to leave the military altogether. Underperforming officials were under considerable career pressure and therefore had an incentive to join the secret police.

One key implication of this study pertains to the security apparatus within nepotist regimes, where loyalty results from favored groups' access to goods and posts. Our argument suggests that individuals without influential networks or career patrons face constraints in reaching the most lucrative regime positions. The lack of personal connections can therefore generate the same pressures as the shortage of merit in other regimes. As such, this study may also explain puzzling cases where individuals from excluded segments of society have served in key coercive units. Similar to merit-based systems, sidelined or even excluded agents should perceive secret police service as a way to advance their careers within nepotist regimes.

A second key implication concerns the institutional roots of authoritarian stability. Conventional wisdom sees patrimonial relations as key elements of a durable autocratic architecture. By contrast, our study shows that an institutionalized, meritocratic bureaucracy does not contradict autocratic longevity. Hierarchical organizations with established career trajectories and merit-based promotion systems produce the incentives for unconditional loyalty, which can be exploited by regimes. Even in such an institutionalized apparatus, individuals may be willing to serve their leaders and ruthlessly target societal opposition groups. This might be bad news for democracies, where performance-based careers are the cornerstone of the state apparatus. Our study explains how governments can accomplish swift autocratic turns without major bureaucratic resistance. Officials facing career pressures are likely to serve as willing executioners, while their wellplaced peers remain silent bystanders.

Finally, this study also points to unintended consequences of transitional justice measures. Our argument implies that future punishment makes secret police service even more costly. However, the looming risks of discharge and incarceration are unlikely to fully drain the pool of willing executioners, as the least competent agents with the lowest career prospects will still gamble on gains from loyal regime service. Imminent sanctions may therefore entail increased suffering for civilians, as poorly qualified agents lack the skills and incentives to target regime enemies selectively.

\section{References}

Albrecht, Holger, and Dorothy Ohl. 2016. "Exit, Resistance, Loyalty: Military Behavior during Unrest in Authoritarian Regimes." Perspectives on Politics 14(1): 38-52.

Amnesty International. 1977. Torture in Greece: The First Torturers' Trial 1975. London: Amnesty International.

Arendt, Hannah. 2017. The Origins of Totalitarianism. New York: Penguin.

Atkins, George P., and Larry V. Thompson. 1972. "German Military Influence in Argentina, 1921-1940.” Journal of Latin American Studies 4(2): 257-74.

Baker, George P., Michael C. Jensen, and Kevin J. Murphy. 1988. "Compensation and Incentives: Practice vs. Theory." Journal of Finance 43(3): 593-616.

Balcells, Laia, and Christopher M. Sullivan. 2018. "New Findings from Conflict Archives: An Introduction and Methodological Framework." Journal of Peace Research 55(2): 13746.

Baldwin, Roger N. 1934. "Political Police." In Encyclopedia of the Social Sciences, Volume XII, ed. Edwin R. A. Seligman and Alvin Johnson. New York: MacMillan, 203-7.

Barros, Robert. 2016. "On the Outside Looking In: Secrecy and the Study of Authoritarian Regimes." Social Science Quarterly 97(4): 953-73.

Becker, Howard S., and Anselm L. Strauss. 1956. "Careers, Personality, and Adult Socialization." American Journal of Sociology 62(3): 253-63. 
Bellin, Eva. 2004. "The Robustness of Authoritarianism in the Middle East: Exceptionalism in Comparative Perspective." Comparative Politics 36(2): 139-57.

Biderman, Albert D., and Laure M. Sharp. 1968. "The Convergence of Military and Civilian Occupational Structures: Evidence from Studies of Military Retired Employment." American Journal of Sociology 73(4): 381-99.

Blau, Peter M., and W. Richard Scott. 2003. Formal Organizations: A Comparative Approach. Stanford, CA: Stanford University Press.

Blažek, Petr, and Pavel Žáček. 2005. "Czechoslovakia.” In $A$ Handbook of the Communist Security Apparatus in East Central Europe, 1944-1989, ed. Krzysztof Persak and Lukasz Kamiński. Warsaw: Institute of National Remembrance, 87161.

Brehm, John, and Scott Gates. 1999. Working, Shirking, and Sabotage: Bureaucratic Response to a Democratic Public. Ann Arbor: University of Michigan Press.

Brooks, Risa. 1998. Political-Military Relations and the Stability of Arab Regimes. Oxford: Oxford University Press.

Browder, George C. 1996. Hitler's Enforcers: The Gestapo and the SS Security Service in the Nazi Revolution. Oxford: Oxford University Press.

Browning, Christopher R. 1998. Ordinary Men: Reserve Police Battalion 101 and the Final Solution in Poland. New York: Harper Perennial.

Cole, Wade M. 2015. "Mind the Gap: State Capacity and the Implementation of Human Rights Treaties." International Organization 69(2): 405-41.

Conrad, Courtenay R., and Will H. Moore. 2010. "What Stops the Torture?" American Journal of Political Science 54(2): 459-76.

Davenport, Christian. 2007. "State Repression and the Tyrannical Peace." Journal of Peace Research 44(4): 485-504.

Deletant, Dennis. 2005. "Romania." In A Handbook of the Communist Security Apparatus in East Central Europe, 1944-1989, ed. Krzysztof Persak and Lukasz Kamiński. Warsaw: Institute of National Remembrance, 285-328.

DeMeritt, Jacqueline H. R. 2015. "Delegating Death: Military Intervention and Government Killing." Journal of Conflict Resolution 59(3): 428-54.

Dinges, John. 2004. The Condor Years: How Pinochet and His Allies Brought Terrorism to Three Continents. New York: New Press.

Dragu, Tiberiu, and Adam Przeworski. 2019. "Preventive Repression: Two Types of Moral Hazard.” American Political Science Review 113(1): 77-87.

Dragu, Tiberiu, and Yonatan Lupu. 2018. "Collective Action and Constraints on Repression at the Endgame." Comparative Political Studies 51(8): 1042-73.

Droz-Vincent, Philippe. 2007. "From Political to Economic Actors: The Changing Role of Middle Eastern Armies." In Debating Arab Authoritarianism: Dynamics and Durability in Nondemocratic Regimes, ed. Oliver Schlumberger. Stanford, CA: Stanford University Press, 195-211.

Dudek, Antoni, and Andrzej Paczkowski. 2005. "Poland.” In A Handbook of the Communist Security Apparatus in East Central Europe, 1944-1989, ed. Krzysztof Persak and Lukasz
Kamiński. Warsaw: Institute of National Remembrance, 221-83.

Egorov, Georgy, and Konstantin Sonin. 2011. "Dictators and Their Viziers: Endogenizing the Loyalty-Competence Tradeoff." Journal of the European Economic Association 9(5): 90330.

Figueroa, Abelardo Martín. 2008. Promociones Egresadas del Colegio Militar de la Nación (1873-2007). Buenos Aires: Sociedad Militar Seguro de Vida Institucion Mutualista.

Frantz, Erica, and Andrea Kendall-Taylor. 2014. “A Dictator's Toolkit: Understanding How Co-optation Affects Repression in Autocracies." Journal of Peace Research 51(3): 33246.

Friedrich, Carl J., and Zbigniew K. Brzezinski. 1965. Totalitarian Dictatorship and Autocracy. Cambridge, MA: Harvard University Press.

Geddes, Barbara, Joseph Wright, and Erica Frantz. 2014. "Autocratic Breakdown and Regime Transitions: A New Data Set." Perspectives on Politics 12(2): 313-31.

Geddes, Barbara, Joseph Wright, and Erica Frantz. 2018. How Dictatorships Work: Power, Personalization, and Collapse. Cambridge: Cambridge University Press.

Gregory, Paul R. 2009. Terror by Quota: State Security from Lenin to Stalin (An Archival Study). New Haven, CT: Yale University Press.

Greitens, Sheena Chestnut. 2016. Dictators and Their Secret Police: Coercive Institutions and State Violence. Cambridge: Cambridge University Press.

Grossman, Dave. 1996. On Killing: The Psychological Cost of Learning to Kill in War and Society. Boston: Back Bay Books.

Harkness, Kristen A. 2016. "The Ethnic Army and the State: Explaining Coup Traps and the Difficulties of Democratization in Africa." Journal of Conflict Resolution 60(4): 587-616.

Hassan, Mai. 2017. "The Strategic Shuffle: Ethnic Geography, the Internal Security Apparatus, and Elections in Kenya." American Journal of Political Science 61(2): 382-95.

Heinz, Wolfgang S. 1999. "Determinants of Gross Human Rights Violations by State and State-Sponsored Actors in Argentina, 1976-1983." In Determinants of Gross Human Rights Violations by State and State-Sponsored Actors in Brazil, Uruguay, Chile, and Argentina, 1960-1990, ed. Wolfgang S. Heinz and Hugo Frühling. Leiden, The Netherlands: Martinus Nijhoff, 593-845.

Huggins, Martha K., Mika Haritos-Fatouros, and Philip G. Zimbardo. 2002. Violence Workers: Police Tortures and Murderers Reconstruct Brazilian Atrocities. Berkeley: University of California Press.

Janowitz, Morris. 1988. The Professional Soldier: A Social and Political Portrait. New York: Free Press.

King, Gary, Michael Tomz, and Jason Wittenberg. 2000. "Making the Most of Statistical Analyses: Improving Interpretation and Presentation." American Journal of Political Science 44(2): 341-55.

Kung, James Kai-sing, and Shuo Chen. 2011. "The Tragedy of the Nomenklatura: Career Incentives and Political Radicalism during China's Great Leap Famine." American Political Science Review 105(1): 27-45. 
Lazear, Edward. 2004. "The Peter Principle: A Theory of Decline." Journal of Political Economy 112(S1): S141-63.

Lewis, Paul H. 2002. Guerrillas and Generals. Westport, CT: Preager.

Lupu, Noam, and Susan C. Stokes. 2009. "The Social Bases of Political Parties in Argentina, 1912-2003.” Latin American Research Review 44(1): 58-87.

McMahon, R. Blake, and Branislav L. Slantchev. 2015. "The Guardianship Dilemma: Regime Security through and from the Armed Forces." American Political Science Review 109(2): 297-313.

Ministerio de Justicia y Derechos Humanos (MJyDH). 2015. "El Batallón de Inteligencia 601." http://www.saij.gob.ar/do cs-f/ediciones/libros/Batallon inteligencia 601.pdf.

Moore, David W., and B. Thomas Trout. 1978. "Military Advancement: The Visibility Theory of Promotion." American Political Science Review 72(2): 452-68.

National Security Archive. 2002a. "Document 13: Subject: Hypothesis-The GOA as Prisoner of Army Intelligence, August 18, 1980." https://nsarchive2.gwu.edu/ NSAEBB/NSAEBB73/800818dos.pdf.

National Security Archive. 2002b. "Document 9: Subject: Nuts and Bolts of the Government's Repression of TerrorismSubversion, August 7, 1979.” https://nsarchive2.gwu.edu/ NSAEBB/NSAEBB73/790807dos.pdf.

Nordlinger, Eric A. 1977. Soldiers in Politics: Military Coups and Governments. Englewood Cliffs, NJ: Prentice-Hall.

Persak, Krzysztof, and Lukasz Kamiński. 2005. A Handbook of the Communist Security Apparatus in East Central Europe, 1944-1989. Warsaw: Institute of National Remembrance.

Plate, Thomas, and Andrea Darvi. 1982. Secret Police: The Inside Story of a Network of Terror. London: Robert Hale.

Policzer, Pablo. 2009. The Rise and Fall of Repression in Chile. Notre Dame, IN: University of Notre Dame Press.

Potash, Robert A. 1996. The Army and Politics in Argentina, 1962-1973: From Frondizi's Fall to the Peronist Restoration. Stanford, CA: Stanford University Press.

Quinlivan, James T. 1999. "Coup-Proofing: Its Practice and Consequences in the Middle East." International Security 24(2): 131-65.
Sassoon, Joseph. 2016. Anatomy of Authoritarianism in the Arab Republics. Cambridge: Cambridge University Press.

Scharpf, Adam. 2018. "Ideology and State Terror: How Officer Beliefs Shaped Repression during Argentina's 'Dirty War.'” Journal of Peace Research 55(2): 206-21.

Slater, Dan. 2003. "Iron Cage in an Iron Fist: Authoritarian Institutions and the Personalization of Power in Malaysia." Comparative Politics 36(1): 81-101.

Stepan, Alfred. 1988. Rethinking Military Politics: Brazil and the Southern Cone. Princeton, NJ: Princeton University Press.

Sudduth, Jun Koga. 2017. "Strategic Logic of Elite Purges in Dictatorships.” Comparative Political Studies 50(13): 17681801.

Svolik, Milan W. 2012. The Politics of Authoritarian Rule. New York: Cambridge University Press.

Taylor, Brian D. 2011. State Building in Putin's Russia: Policing and Coercion after Communism. New York: New York University Press.

Valentino, Benjamin A. 2004. Final Solutions: Mass Killing and Genocide in the Twentieth Century. Ithaca, NY: Cornell University Press.

Zakharov, Alexei V. 2016. "The Loyalty-Competence Trade-off in Dictatorships and Outside Options for Subordinates." Journal of Politics 78(2): 457-66.

Zuckerman, Fredric S. 1996. The Tsarist Secret Police and Russian Society, 1880-1917. New York: New York University Press.

\section{Supporting Information}

Additional supporting information may be found online in the Supporting Information section at the end of the article.

SI.1: Summary statistics

SI.2: Case information

SI.3: Probing the mechanism

SI.4: Additional robustness checks 